\title{
The Adaptation and Validation of the Turkish Version of the Personal Report of Public Speaking Anxiety ${ }^{1}$ (PRPSA)
}

\section{Adaptación y validación de la versión turca del Informe Personal de Ansiedad al Hablar en Público}

\author{
Ramazan Yirci (1) ramazanyirci@gmail.com \\ Seçil Eda Kartal (2) sekartal@bartin.edu.tr \\ Tuncay Yavuz Özdemir (3) tyavuz23@gmail.com \\ Turgut Karaköse (4) tkarakose@yahoo.com \\ Ibrahim Kocabas (5) ibrahimkocabas06@gmail.com \\ (1) Kahramanmaras Sutcu Imam University \\ (2) Bartin University \\ (3) Firat University \\ (4) Dumlupinar University \\ (5)Yildiz Technical University \\ (Received: December 14, 2016; accepted for publishing: April 5, 2017)
}

How to cite: Yirci, R., Kartal, S. E., Özdemir, T. Y., Karaköse, T., \& Kocabas, I. (2018). The adaptation and validation of the Turkish version of the Personal Report of Public Speaking Anxiety (PRPSA). Revista Electrónica de Investigación Educativa, 20(4), 62-71. Retrieved from https://doi.org/10.24320/redie.2018.20.4.1747

\begin{abstract}
The purpose of this study is to adapt the Personal Report of Public Speaking Anxiety (PRPSA) scale into Turkish and study its validity and reliability. The original form of the scale has a single-factor structure and consists of 34 items. The study sample was composed of a total of 322 candidate teachers studying in the School of Education. Three items with fit values below 0.30 from the corrected item-total correlation were excluded from the scale and the analyses were conducted on the remaining 31 items. The construct validity of the scale was confirmed as a single factor through the Mplus software. Cronbach's alpha for the scale was 0.94 , indicating that the scale also has a high level of reliability in the Turkish form. No significant differences were detected between male and female participants' speaking anxiety scores.
\end{abstract}

Keywords: Public speaking, anxiety, rating scales.

\section{Resumen}

El propósito de este estudio fue adaptar la escala "Informe Personal de Ansiedad al Hablar en Público" (PRPSA, por sus siglas en inglés) al turco y hacer estudios de validez-confiabilidad del mismo. La escala original se estructura en un solo factor y consta de 34 ítems. La muestra estuvo conformada por 322 profesores candidatos que estudian en la facultad de Educación. Tres ítems con valores de ajuste por

\footnotetext{
${ }^{1}$ This study is the expanded and developed version of the oral presentation submitted to The European Conference on Educational Research (ECER) held in Budapest, Hungary on 7-11 September 2015.
} 
debajo de 0.30 de la correlación total de ítems corregidos se excluyeron de la escala y se analizaron los 31 ítems restantes. La validez de la escala ha sido confirmada como un factor único por el software Mplus. El alfa de Cronbach presenta una confiabilidad de 0.94, lo que indica que la escala turca tiene también un alto grado de confiabilidad. Con respecto a la variable género no se detectaron diferencias significativas entre los puntajes de ansiedad de habla de los participantes.

Palabras clave: Habilidades comunicativas, ansiedad, escalas de medición.

\section{Introduction}

Many factors affect the essence and quality of education. Teacher competence is a crucial factor that directly affects educational quality. Teachers should have certain competencies to offer a high quality education. It is possible to enhance the quality of education by identifying the competencies that teachers, who play a key role in this process, should possess, and by offering these competencies to teachers through pre-service or in-service training programs (Konokman \& Yelken 2013). Effective communication and speaking skills are an attribute every qualified teacher should have.

One of the most basic functions of today's teachers is to guide students during class, and by making them active in class, bring their students' behavior in line with the school's target. From this perspective, teachers should be trained to meet current requirements. As many scholars have stated, the quality of teachers and teaching is undoubtedly among the most important factors shaping students' learning (Ingersoll, 2004, p. 1; Shieh \& Demirkol, 2014; Ozkan, Albayrak, \& Berber, 2005; Hosgorur \& Apikoglu, 2013). At this point, the importance of teacher training programs has become clear; however, as Morgan (1989) stated, one of the most neglected aspects of teacher training is preparation in the various communication skills needed by good teachers in today's schools. Hargreaves (1995) denounced this situation as it overlooks the emotional nature of teaching.

One important factor in increasing the impact on students is being able to communicate effectively in class. Many studies have reported that teachers with effective communication skills are very successful in establishing positive relationships with students and making them love the lesson (Hamre \& Pianta, 1999; Sen \& Erisen, 2002; Guskey \& Huberman, 1995). Therefore, Andrzejewski $(2008,171)$ argues that this should constitute the sole focus of teacher preparation programs. Some of the basic skills that teachers will inevitably use in class such as planning, instruction, classroom management, communication, reflection, and assessment can be improved through practice. Communication and speaking are key teaching skills that can be improved through practice in university training programs.

The main purpose of this research is to adapt and validate the Turkish version of the Personal Report of Public Speaking Anxiety (PRPSA) for teacher candidates. The validation process involves accumulating evidence to provide a sound scientific basis for the proposed score interpretations (AERA, APA, \& NCME, 1999, as cited in Goodwin \& Leech, 2003). PSA can be described as "a situation-specific social anxiety that arises from the real or anticipated enactment of an oral presentation" (Bodie, 2010, p. 72). Public speaking ability is an important skill for teachers, who should be trained in this area. As stressed by Vangelisti, Daly, \& Friedrich (2013), constructing speeches with accuracy, order, and rigor is vital. Helping individuals to become capable, responsible speakers helps them to become capable, responsible thinkers. However, according to Furmark et al. (1999), about $77 \%$ of the general population fears public speaking. A fear of public speaking causes anxiety and a decrease in achievement and motivation. There can be various reasons for public speaking anxiety, which causes individuals to experience negative feelings such as confusion, trembling, anxiety, tachycardia, a fear of making mistakes, shaking knees, a quivering voice, nausea, low performance in speaking, and a failure to express themselves (American Psychiatric Association, 2000, as cited in Hunter, Westwick, \& Haleta, 2014; Gaibani \& Elmenfi, 2014). It can be said that adapting the public speaking anxiety scale into Turkish will be beneficial due to the high rate of public speaking anxiety and the resulting pressure experienced by individuals. Indeed, ascertaining teacher candidates' public speaking anxiety levels may help to solve the problems that novice teachers face during the first year of their professional career. The findings of this study may help to define teacher candidates' PSA levels and also evaluate the capacity of teacher training programs to provide teacher candidates with the speaking skills they will badly need when teaching. Considering that problems in teacher training are 
universal and similar in most countries, the result of the study will enable educators to consider teacher training programs at university level in a broader framework.

\section{Method}

This section of the study will explain the basic characteristics of the participants, the data collection instrument, and the procedure followed by the researchers.

\subsection{Study sample}

The study sample was composed of 322 randomly-sampled teacher candidates from universities in the Elazig, Bartın and Kahramanmaras provinces of Turkey in the 2014-2015 academic year.

Table I. Demographic characteristics of teacher candidates

\begin{tabular}{lcc}
\hline Branch & Frequency & $\%$ \\
\hline Classroom teachers & 20 & 6.2 \\
Social science teachers & 117 & 36.3 \\
Science teachers & 134 & 41.6 \\
Others & 51 & 15.8 \\
\hline Gender & Frequency & $\%$ \\
\hline Male & 122 & 37.9 \\
Female & 200 & 62.1 \\
\hline Age & Frequency & $\%$ \\
\hline $18-23$ & 190 & 59.0 \\
$24-29$ & 102 & 31.7 \\
$30+$ & 30 & 9.3 \\
\hline Total & 322 & 100.0 \\
\hline
\end{tabular}

It is evident from Table I that the majority of the participants are science teachers. Teachers under "others" consist of physical training and sports teachers and arts and visual arts teachers. The number of female teacher candidates participating in the research is higher than the number of male teacher candidates. The fact that the teaching profession is generally preferred by women has led to an increase in the number of females in the field (Ingersoll, Merrill, \& Stuckey, 2014; Ozoğlu, Gur, \& Altinoglu, 2013). Table I also displays the age interval of the participants. It is clear that the majority of participants are aged between 18 and 23. Those over 30 years old might be second-career seekers who are not satisfied with their current jobs.

\subsection{Data collection instrument}

The researchers gathered data through the PRPSA developed by McCroskey (1970) and Richmond and McCroskey (1992). The questionnaire consists of 34 questions that measure feelings associated with giving a presentation and has been reported as unidimensional. Participants were asked to indicate the degree to which the statements apply to them by marking whether they strongly agree (1), agree (2), are undecided (3), disagree (4), or strongly disagree (5) with each statement (Kostić-Bobanović, 2007). According to Richmond and McCroskey (1992), normalized PRPSA scores are divided into five categories (numbers in parentheses are the percentages of a normalized population fitting each category): scores between 34-84 indicate low anxiety (5\%); 85-92, moderately low anxiety (5\%); 93-110, moderate anxiety (20\%); 111-119, moderately high anxiety (30\%); and 120-170, high anxiety (40\%). Mean scores on the PRPSA have rarely been reported, as the instrument was designed and used primarily for identifying highly anxious students. While 22 of the 34 items in the scale express a negative opinion, 12 items have positive meanings and were reverse-coded. This was the case for items $4,6,7,8,11,12,15,16,17,18,24$, and 26. Thus, the scores obtained from the scale were collected in a single direction. 


\subsection{Procedure and findings}

In the first phase of the adaptation process, the original English forms were translated into Turkish by two expert faculty members from the School of Education and an English language expert from the School of Foreign Languages. Then, the Turkish forms were back-translated and the language consistency between the two forms was reviewed. After the relevant corrections, the translated forms were examined by two faculty members competent in the field of measurement and evaluation. Hambleton and Kanjee (1993) mention that translators who are familiar with the target group and their language, who understand the content of the instrument and have received some training in instrument development, are most capable of producing a first-rate translation.

In the next phase, the latest form of the scale was used to collect data. For construct validity, a confirmatory factor analysis was conducted, before which the Kolmogorov-Smirnov test results were examined for each item in the PRPSA scale. According to the analysis results, normality was ensured for each item $(P>0.05)$. The scale's internal consistency reliability, item analysis, and corrected item-total correlations were examined and the validity and reliability analysis was performed using SPSS 23.0 and Mplus. After the Item-Total Statistics analysis, 3 items were excluded from the form as the corrected itemtotal correlation loadings of these items were below .30. The item-total statistics analysis was repeated on 31 items.

Table II. Item-total descriptive statistics results

\begin{tabular}{|c|c|c|c|c|c|}
\hline Item & Mean & $\begin{array}{c}\text { Std. } \\
\text { Deviation }\end{array}$ & $\begin{array}{l}\text { Scale Mean if } \\
\text { Item Deleted }\end{array}$ & $\begin{array}{c}\text { Scale Variance } \\
\text { if Item } \\
\text { Deleted }\end{array}$ & $\begin{array}{l}\text { Corrected } \\
\text { Item-Total } \\
\text { Correlation }\end{array}$ \\
\hline 1 & 2.93 & 1.301 & 94.3146 & 504.035 & .614 \\
\hline 2 & 2.71 & 1.263 & 94.5296 & 503.169 & .650 \\
\hline 3 & 2.70 & 1.181 & 94.5452 & 508.942 & .587 \\
\hline 4 & 3.19 & 1.215 & 94.0530 & 506.738 & .610 \\
\hline 5 & 2.59 & 1.227 & 94.6449 & 509.873 & .546 \\
\hline 6 & 3.20 & 1.181 & 94.0467 & 519.588 & .383 \\
\hline 7 & 3.12 & 1.226 & 94.1277 & 503.906 & .658 \\
\hline 8 & 2.87 & 1.275 & 94.3707 & 509.215 & .535 \\
\hline 9 & 2.91 & 1.195 & 94.3333 & 506.267 & .631 \\
\hline 10 & 2.44 & 1.227 & 94.8162 & 516.425 & .428 \\
\hline 11 & 3.17 & 1.218 & 94.0810 & 515.618 & .443 \\
\hline 12 & 3.48 & 1.192 & 93.7632 & 516.888 & .430 \\
\hline 13 & 2.62 & 1.079 & 94.6293 & 518.015 & .457 \\
\hline 14 & 2.61 & 1.002 & 94.6355 & 518.314 & .489 \\
\hline 15 & 2.38 & 1.007 & 94.8660 & 518.923 & .472 \\
\hline 16 & 2.69 & 1.206 & 94.5545 & 508.079 & .590 \\
\hline 17 & 2.91 & 1.294 & 94.3302 & 509.584 & .520 \\
\hline 18 & 3.41 & 1.233 & 93.8380 & 501.742 & .694 \\
\hline 19 & 3.04 & 1.232 & 94.2056 & 503.401 & .664 \\
\hline 20 & 2.96 & 1.221 & 94.2866 & 500.574 & .723 \\
\hline 21 & 3.17 & 1.211 & 94.0779 & 505.772 & .631 \\
\hline 22 & 2.49 & 1.033 & 94.7570 & 516.235 & .518 \\
\hline 23 & 3.37 & 1.098 & 93.8692 & 515.883 & .493 \\
\hline 24 & 2.69 & 1.228 & 94.5514 & 507.411 & .591 \\
\hline 25 & 2.87 & 1.226 & 94.3707 & 502.790 & .681 \\
\hline 26 & 2.84 & 1.186 & 94.4050 & 509.167 & .580 \\
\hline 27 & 2.37 & 1.178 & 94.8785 & 509.407 & .581 \\
\hline 28 & 2.63 & 1.350 & 94.6075 & 512.802 & .442 \\
\hline 29 & 3.25 & 1.272 & 93.9938 & 501.300 & .682 \\
\hline 30 & 3.10 & 1.272 & 94.1526 & 504.742 & .616 \\
\hline 31 & 3.01 & 1.318 & 94.2368 & 502.538 & .632 \\
\hline
\end{tabular}

Table II displays the values of the descriptive statistics and the impact on the reliability coefficient if items are excluded from the scale. The arithmetic mean, variance and corrected item-total correlation values can 
be observed for each item. According to Table II, each item has an equal contribution to the scale. These results suggest that all items contribute to the overall score reliability of the scale.

The Kaiser-Meyer-Olkin value was examined before conducting the exploratory factor analysis and the $\mathrm{KMO}$ value was observed to be .945. The Bartlett's test result indicates that an exploratory factor analysis can be conducted $(p=.00<.05)$. Therefore, an exploratory factor analysis was conducted on the data set based on the varimax principal component analysis method. The means of the explained variance and eigenvalues, according to the exploratory factor analysis, are given in Table III.

Table III. Eigenvalues and explained variance according to the results of the exploratory factor analysis

\begin{tabular}{ccc}
\hline Components & Eigenvalues & $\%$ Variance \\
\hline 1 & 11.556 & 37.278 \\
2 & 2.573 & 8.300 \\
3 & 1.458 & 4.702 \\
4 & 1.196 & 3.858 \\
\hline
\end{tabular}

It can be concluded from Table III that there are four components with eigenvalues above 1. This suggests that the scale may be four-dimensional. However, when the eigenvalues of the factors and explained variance are examined, the eigenvalue of the first factor and explained variance are approximately five times greater than the other three. As the first factor explained most of the variance, the scale can be thought of as unidimensional. The original form of the scale was also designed as a single-factor scale. (Slocum-Gori \& Zumbo, 2011; Kaya, 2005, as cited in Duru \& Balkis, 2007; Kubiatko \& Arik, 2014; Gorsuch, 2003, as cited in Slocom, 2005, p. 33; Yirci, Karaköse, Uygun, \& Özdemir, 2016; Williams, Browns, \& Onsman, 2012).

In order to verify the scale's single-factor structure, a confirmatory factorial analysis was carried out using the Mplus software. The Mplus software helps users in tasks such as developing a structural equation model, operating the model and evaluating multiple-level data (Muthén \& Muthén, 1998-2010; Byrne, 2013). In a confirmatory factor analysis, the proposed model is examined and evaluated according to several indices. Various model fit indices are used to evaluate how well the proposed model fits the data. Examining several statistical and practical indices in order to determine whether or not to reject a particular model is very important (Brown, 2006; Heck \& Thomas, 2015, p. 51). The values of some goodness-of-fit indices are more or less standardized as a range of 0-1.0, where a value of 1.0 indicates the best fit (Kline, 2015). Here are some indices and their value ranges showing acceptable model fit: $0.05 \leq R M S E A \leq 0.08,0.05 \leq S R M R \leq 0.10,0.95 \leq C F I \leq 0.97,0.90 \leq T L I \leq 0.10,0.94 \leq \mathrm{NFI} \leq 0.90$ (Schermelleh-Engel, Moosbrugger \& Müller, 2003; Kline, 2011; Hooper, Coughlan, \& Mullen, 2008; Wang \& Wang, 2012). The fit indices in this study suggest that the model has a good fit $\left(x^{2}=840.891, \mathrm{df}=403\right.$, RMSEA $=.008, \mathrm{NFI}=.94$, $\mathrm{TLI}=.88$, SRMR=.059) (Hu \& Bentler, 1999). The Cronbach's alpha coefficient for the scale is $a=.94$.

The path diagram for the exploratory factor analysis conducted with the Mplus software is shown in Figure 1. It can be observed that the single-factor model is valid and the factor loadings of the scale range between .39 and 92 . 


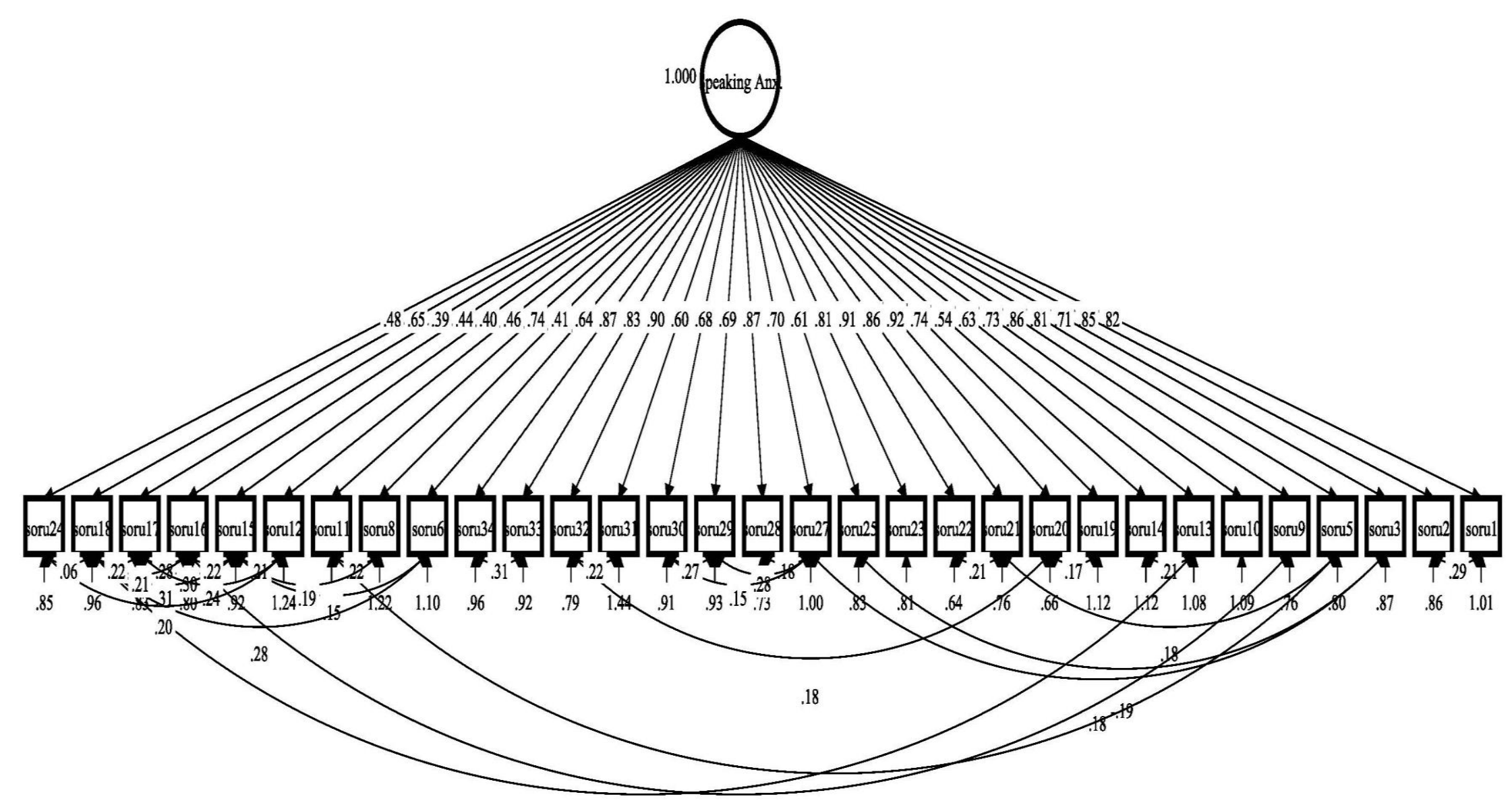

Fit indices: $\mathrm{X}^{2}=840.891, \mathrm{df}=403, \mathrm{RMSEA}=.008, \mathrm{NFI}=.94, \mathrm{TLI}=.88, \mathrm{SRMR}=.059$

Figure 1. Path diagram for the unidimensional model of the PRPSA 
The study also examined whether or not the gender variable differs significantly, with the aim of adapting the PRPSA scale into Turkish. The results of the independent sample t-test are given in Table IV.

Table IV. Public Speaking Anxiety Scale and results of the t-test on the gender variable

\begin{tabular}{|c|c|c|c|c|c|c|c|}
\hline \multirow{2}{*}{ Gender } & \multirow{2}{*}{$\mathrm{n}$} & \multirow{2}{*}{$\bar{X}$} & \multirow{2}{*}{ SD } & \multirow{2}{*}{$t$} & \multirow{2}{*}{$\mathrm{P}$} & \multicolumn{2}{|c|}{ Levene's test } \\
\hline & & & & & & $f$ & $p$ \\
\hline Male & 122 & 2.70 & .594 & -3.281 & .001 & 3.475 & .063 \\
\hline Female & 200 & 2.96 & .717 & -3.281 & .001 & 3.415 & \\
\hline
\end{tabular}

Table IV shows a significant difference between genders in the mean scores obtained from the Public Speaking Anxiety Scale. Female participants' mean scores $(\bar{X}=2.96)$ were observed to be higher than those of males $(\bar{X}=2.96)$, and this difference was statistically significant $(p=0.001<0.05)$. This result indicates that female teacher candidates have a higher level of public speaking anxiety than male teacher candidates. There are various findings in this respect in the literature. For example, Matsuda and Gobel (2004) and Wang (2010) found that there was no significant difference in speaking anxiety according to gender. However, some studies, such as McCroskey, Gudykunst, and Nichida (1985), Mejias, Applebaum, Applebaum, and Trotter (1991), and Behnke and Sawyer (2001), have indeed shown a significant relationship between speaking anxiety and the gender variable, in that females have higher speaking anxiety levels than males.

During data collection, the participants were asked if they had received any lessons regarding communication or speaking skills in college. The results for this question can be seen in Table V.

Table V. Did you have a lesson on "communication" in college?

\begin{tabular}{c|c|c}
\hline $\begin{array}{c}\text { Student } \\
\text { response }\end{array}$ & Frequency & $\%$ \\
\hline Yes & 116 & 36.0 \\
No & 206 & 64.0 \\
\hline Total & 322 & 100.0 \\
\hline
\end{tabular}

The results in Table $V$ show that most teacher candidates in Turkey (64\%) have not taken a lesson on communication, suggesting that curricula in teacher training departments in universities should be redesigned to include compulsory lessons on communication.

\section{Conclusion}

The main purpose of this research is to adapt and validate the Turkish version of the PRPSA for teacher candidates. In this respect, the effectiveness of equipping students with communication and speaking skills in current teacher training programs in universities is clear. The study sample was composed of 322 teacher candidates from Elazig, Bartin and Kahramanmaras. Data was collected through the PRPSA scale from students selected by random sampling. This data was then analyzed with the sPSS and Mplus software.

The coefficient for the Turkish version of the scale indicates that it has adequate reliability (Sipahi, Yurtkoru, \& Çinko, 2008). The findings of the reliability and validity analysis show that the Turkish version of the PRPSA is ready for use in a Turkish context. The latest form of the Turkish version of the scale consists of 31 items and possible scores range from 31 to 155. The higher the score, the higher the participant's degree of public speaking anxiety. According to the analysis, Turkish teacher candidates show a moderately high level of public speaking anxiety. This suggests that traditional teacher training programs in Turkey are insufficient to equip teacher candidates with the necessary speaking skills. From this perspective, it seems necessary to adapt teacher training programs urgently. 
The study also has a few limitations. Firstly, the study sample only included teacher candidates studying in college. Future studies could examine the public speaking anxiety levels of novice trainee teachers. According to the confirmatory factor analysis of the single-factor structure of the PRPSA scale, the scale has acceptable fit values. As a result, it could be used in future studies to research public speaking anxiety levels in university students studying in various other socially valued professional degree programs.

\section{References}

Andrzejewski, C. E. (2008). A holistic investigation of teacher identity, knowledge, and practice. Unpublished doctoral dissertation, Graduate School of The Ohio State University, USA.

Behnke, R. R., \& Sawyer, C. R. (2001). Patterns of psychological state anxiety in public speaking as a function of anxiety sensitivity. Communication Quarterly, 49, 85-94.

Bodie, G. D. (2010). A racing heart, rattling knees, and ruminative thoughts: Defining, explaining, and treating public speaking anxiety. Communication Education, 59, 70-105.

Brown, T. A. (2006). Confirmatory factor analysis for applied research. New York: Guilford.

Byrne, B. M. (2013). Structural equation modeling with Mplus: Basic concepts, applications, and programming. New York: Routledge.

Duru, E., \& Balkis, M. (2007). Sosyal provizyon olçeginin psikometrik ozellikleri: Gecerlik ve guvenirlik calismasi. Turk Psikolojik Danisma ve Rehberlik Dergisi, 27, 79-90.

Furmark, T., Tillfors, M., Everz, P., Marteinsdottir, I., Gefvert, O., \& Fredrikson, M. (1999). Social phobia in the general population: prevalence and sociodemographic profile. Social Psychiatry and Psychiatric Epidemiology, 34(8), 416-424.

Gaibani, A., \& Elmenfi, F. (2014). The role of gender in influencing public speaking anxiety. British Journal of English Linguistics, 2(3), 7-13.

Goodwin, L. D., \& Leech, N. L. (2003). The meaning of validity in the new standards for educational and psychological testing: Implications for measurement courses. Measurement and Evaluation in Counseling and Development, 36(3), 181-192.

Guskey, T., \& Huberman, M. (1995). Professional development in education: New paradigms and practices. New York: Teachers College.

Hambleton, R. K., \& Kanjee, A. (1993). Enhancing the validity of cross-cultural studies: improvements in instrument translation methods. Retrieved from https://eric.ed.gov/?id=ED362537

Hamre, B. K., \& Pianta, R. C. (1999). Enhancing relationships between children and teachers. Washington: American Psychological Association.

Hargreaves, A. (1995). Development and desire: A postmodern perspective. In T. R. Guskey \& M. Huberman (Eds.), Professional development in education: New paradigms and practices (pp. 9-34). New York: Teachers College.

Heck, R. H., \& Thomas, S. L. (2015). An introduction to multilevel modeling techniques: MLM and SEM approaches using Mplus. East Sussex: Routledge.

Hooper, D., Coughlan, J., \& Mullen, M. (2008). Structural equation modelling: Guidelines for determining model fit. Electronic Journal of Business Research Methods, 6(1), 53-60. 
Hosgorur, T., \& Apikoglu, S. (2013). Relationship between school administrators' anxiety levels for authority use and burnout levels. Educational Process: International Journal, 2(1-2), 19-35.

Hu, L. T., \& Bentler, P. M., (1999). Cutoff criteria for fit indexes in covariance structural analysis: Conventional criteria versus new alternatives. Structural Equation Modeling, 6, 1-55.

Hunter, K. M., Westwick, J. N., \& Haleta, L. L. (2014). Assessing success: The impacts of a fundamentals of speech course on decreasing public speaking anxiety. Communication Education, 63(2), 124-135.

Ingersoll, R. M. (2004). Four myths about America's teacher quality problem. In M. A. Smylie \& D. Miretzky (Eds.), Developing the teacher workforce (pp. 1-14). Chicago: University of Chicago Press.

Ingersoll, R., Merrill, L., \& Stuckey, D. (2014). Seven trends: The transformation of the teaching force. CPRE Research Report \#RR-80. Philadelphia: Consortium for Policy Research in Education.

doi:10.12698/срге.2014.гг80

Kline, R. B. (2015). Principles and practice of structural equation modeling. New York: The Guilford Press.

Konokman, G. Y., \& Yelken, T. Y. (2013). Öğretmen adaylarının öğrenme öğretme süreci alanındaki yeterliklerine ilişkin görüşleri. Mersin Üniversitesi Eğitim Fakültesi Dergisi, 9(1), 175-188.

Kostić-Bobanović, M. (2007). Coping with Public Speaking Anxiety. In Creative Organization. Hrvatskaznanstvenabibliografija i Mzos-Svibor.

Kubiatko, M., \& Arik, R. S. (2014). Comparison of the effects of gender variable on attitudes towards the teaching profession by random and fixed effects model: Meta-Analysis. Educational Process: International Journal, 3(1-2), 52-64.

Matsuda, S., \& Gobel, P. 2004. Anxiety and predictors of performance in the foreign language classroom. System, 32(1), 21-36.

McCroskey, J. C. (1970). Measures of communication-bound anxiety. Speech Monographs, 37, 269-277.

McCroskey, J. C. (1977). Oral communication apprehension: A summary of recent theory and research. Human Communication Research, 4(1), 78-96.

McCroskey, J. C., \& Richmond, V. P. (1992). Communication apprehension and shyness: Conceptual and operational distinction. Central States Speech Journal, 33, 458-468.

McCroskey, J. C., Gudykunst, W. B., \& Nichida. T. (1985). Communication apprehension among Japanese students in native and second language. Communication research reports, 2(1).

Mejías, H., Applebaum, R. L., Applebaum S. J., \& Trotter, R. T. (1991). Oral communication apprehension and Hispanics: An exploration of oral communication apprehension among Mexican American students in Texas. In E. K. Horwitz \& D. J. Young (eds.), Language Anxiety: From Theory and Research to Classroom Implications, 87-97. Englewood Cliffs, NJ: Prentice Hall.

Morgan, A. L. (1989). Communication skills for teachers. Retrieved from http://eric.ed.gov/?id=ED312729

Muthén, L. K., \& Muthén, B. O. (1998-2010). Mplus user's guide (6th ed.). Los Angeles, CA: Muthén \& Muthén. Retrieved from www.statmodel.com

Ozkan, H., Albayrak, M., \& Berber, K. (2005). Oğretmen Adaylarinin Ilkogretim Okullarinda Yaptiklari Ogretmenlik Uygulamasinin Yetismelerindeki Rolu. Milli Egitim Dergisi, Ankara, Sayı-168. 
Ozoğlu, M., Gur, B. S., \& Altinoglu, A. (2013). Turkiye ve Dunyada Ogretmenlik. Ankara, Turkey: Egitim Bir Sen.

Schermelleh-Engel, K., Moosbrugger, H., \& Müller, H. (2003). Evaluating the fit of structural equation models: Tests of significance and descriptive goodness-of-fit measures. Methods of Psychological Research Online, 2(8), 23-74.

Sen, H. S., \& Erisen, Y. (2002). Ogretmen Yetistiren Kurumlarda Ogretim Elemanlarinin Etkili Ogretmenlik Ozellikleri. Gazi Universitesi Gazi Egitim Fakultesi Dergisi, 22(1), 99-116.

Shieh, C.J,. \& Demirkol, M. (2014). Evaluation of the effectiveness of social networks and their usage by high school students. Educational Process: International Journal, 3(1-2), 7-18.

Sipahi, B., Yurtkoru, E. S., \& Çinko, M. (2008). Sosyal Bilimlerde sPSs'le Veri Analizi. Istanbul: Beta Basım Yayım Dağıtım.

Slocum, S. L. (2005). Assessing unidimensionality of psychological scales: Using individual and integrative criteria from factor analysis. Unpublished Doctoral Dissertation, University of British Columbia, Canada.

Slocum-Gori, S. L., \& Zumbo, B. D. (2011). Assessing the unidimensionality of psychological scales: Using multiple criteria from factor analysis. Social Indicators Research, 102(3), 443-461.

Vangelisti, A. L., Daly, J. A., \& Friedrich, G. W. (2013). Teaching communication: Theory, research, and methods. London: Routledge.

Wang, J., \& Wang, X. (2012). Structural equation modeling: Applications using Mplus. West Sussex, England: John Wiley \& Sons.

Wang, T. (2010). Speaking anxiety: More of a function of personality than language achievement. Chinese Journal of Applied Linguistics, 5(33).

Williams, B., Brown, T., \& Onsman, A. (2012). Exploratory factor analysis: A five-step guide for novices. Australasian Journal of Paramedicine, 8(3), 1-13.

Yirci, R., Karaköse, T.,Uygun, H., \& Özdemir, T. Y. (2016). The Turkish adaptation of the Mentorship Effectiveness Scale: A validity and reliability study. Eurasia Journal of Mathematics, Science \& Technology Education, 12(4), 821-832. 